\title{
SUBJECTIVE ASSESSMENT OF HEALTH AND QUALITY OF LIFE IN WOMEN USING HORMONAL CONTRACEPTIVES
}

\section{SUBIEKTYWNA OCENA ZDROWIA I JAKOŚCI ŻYCIA WŚRÓD KOBIET STOSUJĄCYCH ANTYKONCEPCJĘ HORMONALNĄ}

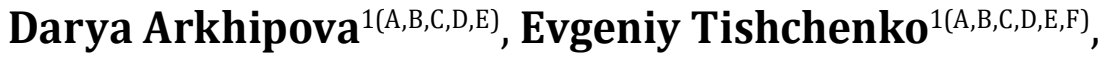 \\ Pavel Shauliuk $^{1(B, F)}$, Yulia Kukharchik ${ }^{1(B, F)}$
}

Authors' contribution
Wkład autorów:
A. Study design/planning
zaplanowanie badań
B. Data collection/entry
zebranie danych
C. Data analysis/statistics
dane - analiza i statystyki
D. Data interpretation
interpretacja danych
E. Preparation of manuscript
przygotowanie artykułu
F. Literature analysis/search
wyszukiwanie i analiza literatury
G. Funds collection
zebranie funduszy
Tables: 0

Figures: 7

References: 17

Submitted: 13.07.2015

Accepted: 08.02.2016
${ }^{1}$ Grodno State Medical University, the Republic of Belarus

\begin{abstract}
Summary
Background. Modern hormonal contraceptives are effective remedies for the prevention of undesirable pregnancies, have a positive impact on the health of women, and serious complications at their using meet seldom. However, 30-50\% of women refuse to hormonal contraception during the first year of using. The main reasons for the refusal are side effects and a fear of their appearing. Material and methods. Our objective was to study the influence of hormonal contraceptives on the health and quality of life of women. We carried out the anonymousquestioning of 145 patients at the age of 20-39 years which were on a treatment in obstetric and gynecological hospitals of the Grodno region and ever used hormonal contraceptives.

Results. Hormonal contraceptives are highly effective at regular using. Side effects are widespread and were found in 9 of $10(90.4 \%)$ women. However in $73.3 \%$ of cases they disappear during the first 3 months. Some women admitted that new diseases were diagnosed for them in a usage time of hormonal contraception. Gastritis was almost at every fifth respondent $(18.6 \%)$, that requires attention.

Conclusions. The most of women are satisfied with hormonal contraception. The half of respondents are ready to continue using despite side effects, and every third - if other hormonal contraceptive will be suitable. The quality of life of the women using hormonal contraceptives can be estimated as close to average norm.
\end{abstract}

Keywords: contraception, hormonal oral contraceptives, combined oral contraceptives, ovulation inhibition, drug-related side effects and adverse reactions, quality of life, reproductive health, women's health

\section{Streszczenie}

Wprowadzenie. Nowoczesna antykoncepcja hormonalna to skuteczna metoda zapobiegania niechcianym ciążom, mająca zarazem pozytywny wpływ na zdrowie kobiet, w przypadku której bardzo rzadko mamy do czynienia z poważnymi komplikacjami związanymi z jej stosowaniem. Jednakże, 30-50\% kobiet odstępuje od stosowania antykoncepcji hormonalnej w ciągu pierwszego roku od rozpoczęcia jej stosowania. Głównymi powodami są działania uboczne, a także strach przed ich pojawieniem się.

Materiał i metody. Celem naszego badania była analiza wpływu antykoncepcji hormonalnej na zdrowie oraz jakość życia kobiet. Przeprowadziliśmy anonimową ankietę, która objęła 145 pacjentek w wieku 20-39 lat, które były leczone w szpitalach ginekologiczno-położniczych w regionie Grodna, a które stosowały w dowolnym okresie swojego życia antykoncepcję hormonalna.

Wyniki. Antykoncepcja hormonalna jest wysoce skuteczna przy regularnym jej stosowaniu. Efekty uboczne są bardzo czeste, gdyż rozpoznano je w przypadku 9 na 10 kobiet $(90.4 \%)$. Jednakże, w przypadku 73.3\% zanikają one $\mathrm{w}$ trakcie pierwszych 3 miesięcy stosowania. Część kobiet przyznała, że wykryto u nich nowe choroby w trakcie stosowania antykoncepcji hormonalnej. Zapalenie błony śluzowej żołądka zdiagnozowano u co piątej badanej (18.6\%), co jest zapewne warte dalszej uwagi.

Wnioski. Większość kobiet jest zadowolona ze stosowania antykoncepcji hormonalnej. Połowa badanych ma zamiar nadal korzystać z tego środka pomimo efektów ubocznych, a co trzecia kobieta - także z innych hormonalnych środków antykoncepcyjnych, które będą możliwe dla niej do stosowania.

Słowa kluczowe: antykoncepcja, hormonalne, doustne środki antykoncepcyjne, łączone doustne środki antykoncepcyjne, hamowanie owulacji, efekty uboczne związane z lekami, skutki uboczne, jakość życia, zdrowie reprodukcyjne, zdrowie kobiety 


\section{Background}

Hormonal contraceptives are among to the most widely using medicines [1]. According to the World Health Organization (WHO), in the world about 15\% of women of reproductive age use combined oral contraceptives, and in some countries this number reaches $60 \%$ [2].

Despite nearly $100 \%$ efficiency at the correct using of combined oral contraceptives, at the typical using the number of failures for the first year reaches $8-9 \%$ that reflects the fact of frequent refusal of the medicines using. On the other hand, the forgetfulness of women can't affect the efficiency of such methods as intrauterine hormonal contraception or anintroduction of hypodermic implants, and the result at the ideal and typical using coincides [3,4].

The long-timeusing of hormonal contraceptives decreases the relative risk of endometrial and ovariancancer, benign breast tumors, myomas, inflammatory diseases of internal genitals, extrauterine pregnancies, ovarian apoplexy, anemia, colorectal cancer, postmenopausal osteoporosis [1,3-8]. Also hormonal contraceptives help in treatment of premenstrual syndrome, dysmenorrhea, metrorrhagia, endometrial hyperplasia, endometriosis, polycystic ovary syndrome, acne, seborrhea, hirsutism, reduce the number of chronic salpingooforitis exacerbations, promote improvement during rheumatoid arthritis [2,3,5,7,9-13]. After the termination of using combined oral contraceptives more than $85-90 \%$ of women are capable to become pregnant within a year that corresponds to the biological level of fertility [14]. The short-term using (within 3 months) increases sensitivity of receptors of a hypothalamus-hypophysis-ovary system and takes place in the treatment of infertility $[10,14]$.

Serious complications meet seldom if modern hormonal contraceptives used. Side effects usually arise atthe first months of using (at 10-40\% of women), and later their frequency decreases to 5-10\% [1].

The risk of breast cancer whenusing hormonal contraceptives increases slightly [3]. The increase of cervix uteri cancer is noted, but only at the women infected witha human papilloma virus [3,7]. Liver tumors are also sometimes connected with using of oral contraceptives [5]. Hormonal contraception increases the risk of progressing of a disease and death at patients infected with a human immunodeficiency virus [7]. Such complications as deep venous thrombosis and pulmonary embolism can arise at 2-10 times more than in the population, but nevertheless they are rare [5]. Such factors as thromboembolism in anamnesis, age more than 35 years, smoking, excess body weight raise risk degree [3,5]. The risk of ischemic stroke and myocardial infarction when using the low-dosed contraceptives by healthy non-smoking women doesn't increase, however it can increase at patients with arterial hypertension. Besides, the risk of ischemic stroke increases at the patients having migraine with aura [3]. Whenusing hormonal contraceptives the probability of cholestasis and gall bladder diseases can increase [5]. The increased risk of Crohn's disease, and (at the smoking women)ulcerative colitis is revealed [8].

Less serious, but more frequent side effects also depend on a dosage and type of the used hormones. Estrogens can cause body weight increase, breast engorgement, nausea, fatigue, headaches, blood pressure increase, progressing of varix dilatation. Progestagens can be the reason of acne, depression, libido decrease, dry vagina, etc. $[5,14]$. Low-dose hormonal contraceptives have such advantagesas bettertolerance and smaller numberof side effects. At the same time, withdrawal bleedingsafter their usingare more frequent [13].

Informing on possible side effects before they arise, helps to avoid refusals of a method using [9]. If side effects remain within 3-4 months or amplify, the contraceptive should be changed [14].

It is necessary to remember that women with somatic diseases need effective and safe contraception especially [2]. Health risks of women using hormonal contraceptives are much lower (by 10 times and more) than the probability of complications during an undesirable pregnancy, childbirth and abortions [13].

According to WHO data, considerable decrease in the frequency of abortions comes when $50 \%$ of women of fertile age use the effective contraception. In countries of Western Europe $45 \%$ of women use hormonal contraception, and at the age of $18-25$ years there are $70 \%$. As a result, in these countries the lowest level of abortions is noted [9].

By the results of research according to the position of children and women in the Republic of Belarus which is carried out in 2012, $63 \%$ of the women having a partner use contraceptives, $51.2 \%$ of women use modern methods, and only $10.3 \%$ take a contraceptive pill [15].

$30-50 \%$ of women refuse hormonal contraceptives within the first year of using [7]. 20-25\% stop take them within the first 6 months, and the biggest part - within the first 2 months $[3,10]$. Side effects or fear of their appearing are the main causes of failure [3]. The main part of women doesn't consult to a doctor, 24-28\% don't choose a new contraceptive, and the others prefer less effective methods [10].

The result is that the number of artificial abortions among all cases of pregnancy is rather high. In Republic of Belarus in 201313.2 thousand abortions were executed, and there were26.6 abortions on 100 childbirths [16]. Many women start to use contraception having already one or several abortions [17]. 


\section{Material and methods}

Our objective was to study the influence of hormonal contraceptives on the health and quality of life of women at the age of 20-39 years.

We carried out the questioning of 145 patients at the age of 20-39 years which were on a treatment in obstetric and gynecological hospitals of the Grodno region and ever used hormonal contraceptives (oral and parenteral forms). We made the anonymous questionnaire including 19 questions about the state of health before and in thetime of using hormonal contraception and also about the opinion of women about this method. Besides, the WHO Quality of Life-BREF (WHOQOL-BREF) including 26 questions was offered to the patients. Processing of the statistical data was carried out with the Microsoft Excel program. The data were shown as average values and statistical deviations. Reliability was estimated with $\chi 2$, the difference was admitted as statistically significant at $\mathrm{p}<0.05$.

The mean age of the questioned women was $29.0 \pm 0.5$ years. Married women prevailed $-69.0 \%, 21.4 \%$ were not married, $9.0 \%$ were divorced, one was a widow. $73.1 \%$ werecitizens, other $26.9 \%$ were villagers. The most of women had acomplete higher (35.2\%) or secondaryvocational (26.9\%) education. 16.6\% had an incomplete higher education, 5.5\% - incomplete secondary vocational education. $13.8 \%$ of respondents hada general secondaryeducation and $2.1 \%$ had a general basic education. The half of women (53.8\%) had a brainwork, the one of four (24.1\%) had a physical work, $11.0 \%$ werestudents and as much were housewives.

\section{Results}

Four of five questioned women (78.6\%) don't smoke, but every fifth (21.4\%) smokes. The half of respondents (51.0\%) take alcohol once a month and less, every fourth (25.5\%) less than once a week but more than once a month, and some (1.4\%) - once a week and more. Only every fifth woman (22.1\%) doesn't take alcohol at all.

Every seventh (13.8\%) from the questioned women thought that before using hormonal contraceptives she had an overweight, and one of ten (10.3\%) women hada low body weight. At the time of using four of five (73.1\%) respondents had a normal Body Mass Index. However $18.6 \%$ had an overweight, $2.8 \%$ hada I degree obesity, $4.1 \%$ - a low body weight, $1.4 \%$ - a significant weight deficit.

Before the using of hormonal contraception every third (36.6\%) woman had an irregular menstrual cycle, and almost as much (31.7\%) felt severe pains during periods. What's about premenstrual syndrome, more than a half (55.9\%) of respondents noted some psychological manifestations. A nervousness and irritability met at $42.1 \%$, a low mood and depression - at 27.6\%. Two thirds of women (63.4\%) had various physical manifestations before periods like a breast engorgement and pain at $46.2 \%$, an abdominal pain, leg pain, back pain - at $37.2 \%$. The one of three (29.7\%) respondentscomplained ofa greasy skin and hair, acne, 4.8\% - of anexcessive pilosis, $9.7 \%$ - of a dry skin and hair.

Nearly a half (46.9\%) of the questioned women had inflammatory gynecologic diseases in the anamnesis, $17.2 \%$ had ovary cysts, $5.5 \%$ - endometriosis, $8.3 \%$ - infertility. Every fifth $(20.7 \%)$ hadmastopathy, every tenth (9.7\%) -varix dilatation. $18.6 \%$ had digestive tract diseases, $14.5 \%$ - anemia, $8.3 \%$ - diseases of kidneys and a bladder, $6.2 \%$ - arterial hypertension, one respondent had a diabetes.

To choose a hormonal contraceptive most of women $(85.5 \%)$ were consulted by a doctor. The medicine was prescriptedfor contraception in a half (55.2\%) of respondents, and for treatment of gynecological diseases inone of three (30.3\%) women. At the same time, every tenth (10.3\%) used acquaintances advices, $6.2 \%$-articles on the Internet and popular magazines, $4.1 \%$ - pharmacists' advices, one respondent looked for scientific researches (figure 1).

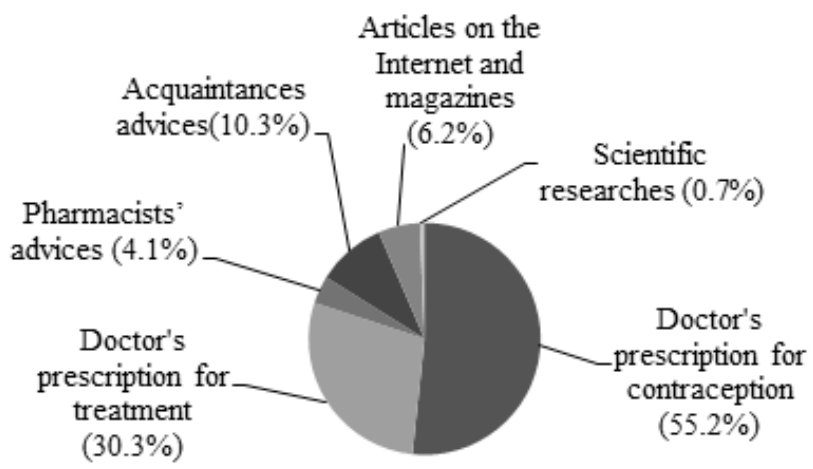

Figure 1. Choice of a hormonal contraceptive 
Housewives used a doctor's advice less (68.8\%) then women with a brainwork (91.1\%) and physical work (82.8\%), and alsoused a pharmacist's advice more (18.8\% against $2.6 \%$ and $0.0 \%) \cdot \chi 12=7.57, \chi 22=6.8, \mathrm{p}<0.05$. The level of education didn't have a significant influence $(\chi 2=5.58, \mathrm{p}<0.05)$.

The most popular were combinations: ethinylestradiol (EE) $30 \mathrm{mkg} /$ desogestrel $150 \mathrm{mkg}-18.1 \%$ of women used it, EE $20 \mathrm{mkg} /$ desogestrel $150 \mathrm{mkg}-15.7 \%$. Also they used: EE $30 \mathrm{mkg} /$ drospirenone $3 \mathrm{mg}-9.6 \%$, intrauterine system withlevonorgestrel $52 \mathrm{mg}-9.0 \%$, EE $20 \mathrm{mkg} /$ gestodene $750 \mathrm{mkg}$, EE $35 \mathrm{mkg} /$ cyproterone acetate $200 \mathrm{mkg}$, EE $30 \mathrm{mkg}$ / dienogest $2 \mathrm{mg}$ - each for 7.8\%, EE of $20 \mathrm{mkg} /$ drospirenone $3 \mathrm{mg}-6.6 \%$. Some women used EE $30 \mathrm{mkg}$ / gestodene $750 \mathrm{mkg}$, EE $50 \mathrm{mkg}$ / levonorgestrel $250 \mathrm{mkg}$ - each for $2.4 \%$, EE $35 \mathrm{mkg}$ / norgestimate $250 \mathrm{mkg}$, EE $30 \mathrm{mkg}$ / levonorgestrel $125 \mathrm{mkg}$, EE $15 \mathrm{mkg} /$ gestodene $60 \mathrm{mkg}$, triphasicEE 30-40 $\mathrm{mkg}$ / levonorgestrel 50-75-125 mkg - each for 1.8\%, estradiol hemihydrate 1,55 mg / nomegestrol acetate 2,5 $\mathrm{mg}$, triphasicestradiol valerate 1-2-3 mg / dienogest 2-3 mg, triphasic EE of 30-35 mkg / desogestrel 50-100-150 $\mathrm{mkg}$ - on 1.2\%. Only one woman used EE $50 \mathrm{mkg} /$ norethisterone acetate $1 \mathrm{mg}$, EE $30 \mathrm{mkg} /$ levonorgestrel 150 $\mathrm{mkg}$, levonorgestrel $30 \mathrm{mkg}$.

The most of women (88.3\%) took only 1 hormonal contraceptive, one of ten (10.3\%) - 2 types, and two women -3 types of hormonal contraceptives. Usingless than 3 months was in 9.6\%, 4-6 months - in 19.3\%, 7-12 months - in $12.7 \%$, 1-3 years - in $46.4 \%$, more than 3 years - in $12.0 \%$.

Nine of ten (90.4\%) respondents reported about different side effects. And only one of ten (9.6\%) women didn't have them. These data don't correlate with that shown in literature and this means that side effects take place more often than it is considered to be. However in the most of cases (73.3\%) side effects disappeared within the first 3 months (figure 2).

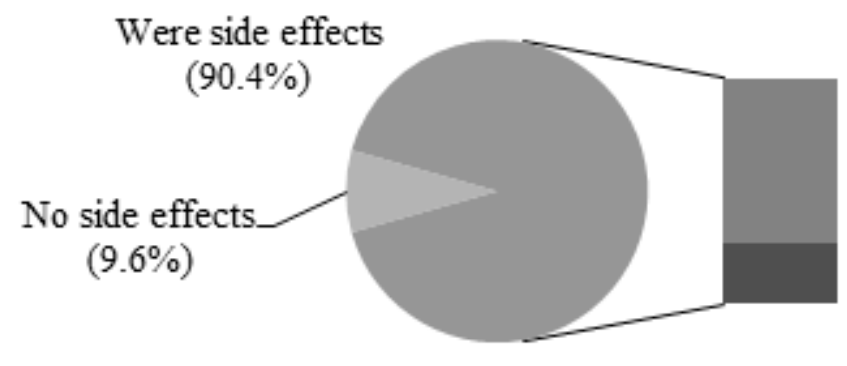

\section{Disappeared within the first 3 months $(73.3 \%)$}

\section{Weren't \\ disappear \\ $(26.7 \%)$}

Figure 2. Side effects

Every fifth woman complained of headaches (21.1\%), mood changes, nervousness (19.3\%)and sleepiness (18.7\%). Every eighth had a depression, low mood, fatigue (13.3\%), dizziness (12.7\%). Also there were decreased libido $-7.8 \%$, sleeplessness $-6.6 \%$, faints $-1.8 \%$.

Blood pressure increase was noted at one of fifteen (6.6\%) respondents, varix dilatation, tachycardia - at $3.0 \%$, nasal bleedings - at $1.8 \%$.

At every fifth $(20.5 \%)$ woman there was an increased appetite, at every sixth $(16.9 \%)$ - a nausea and almost at every tenth (9.0\%) - a heartburn. 5.4\% complained of a diarrhea and abdominal distention, $4.8 \%$ - of constipations and low appetite, $4.2 \%$ - of an abdominal pain, hemorrhoids, $2.4 \%$ - of vomiting, $1.8 \%$ - of a dry mouth.

Approximately at one of ten questioned women there was abreast pain (11.4\%),spotting in the first half of a cycle (9.6\%), breast increase, vaginal candidiasis (9.0\%). Leukorrhagiawas at $6.0 \%$ of women,spotting in the second half of a cycle - at 5.4\%, hypermenorrhea and dysmenorrhea - at $4.8 \%$, vaginal dryness - at $4.2 \%$, dyspareunia - at $2.4 \%$, the absence ofa menstruation-like hemorrhage - at $1.8 \%$.

A body weight increase was observed at every fifth (21.1\%) respondent, a desudation- at every tenth (11.4\%). $7.8 \%$ of respondents complained of an edema, $6.6 \%$ - of acne and greasy skin, $6.0 \%$ - of cellulite and dry skin. Also there was a skin itch - at $4.2 \%$, a back pain, leg pain - at 3.6\%, pigment spots, a hair loss - at $2.4 \%$, a body weight decrease, allergic rash - at $1.8 \%$, an excessive pilosis- at $1.2 \%$ less often.

After 3 months of using such side effects as sleeplessness, vomiting, tachycardia,spotting in the second half of a cycle, vaginal dryness didn't meet any more.

More than at three of four women the following side effects disappeared for the first 3 months: spotting in the first half of a cycle, hypermenorrhea and dysmenorrhea, a low appetite - at $87.5 \%$, vaginal candidiasis - at $86.7 \%$, a nausea, dizziness, abdominal pain, skin itch - at $85.7 \%$, a back pain - at $83.3 \%$, mood changes, nervousness - at $81.3 \%$, sleepiness - at $80.6 \%$, headaches, dry skin - at $80.0 \%$, increased appetite - at $79.4 \%$, a breast pain - at 78.9\%, constipations, hair loss - at 75.0\%. 
Besides, more than at the half of respondents disappeared such side effects asdesudation- at $73.7 \%$, a depression, low mood, fatigue - at 72.7\%, leukorrhagia - at 70.0\%, edemas - at $69.2 \%$, a diarrhea and abdominal distension - at $66.7 \%$, a blood pressure increase - at $63.6 \%$, heartburn - at $60.0 \%$, acne, greasy skin - at $54.5 \%$, a breast increase- at $53.3 \%$, dyspareunia, leg pain - at $50.0 \%$.

However some side effects disappeared in 3 months less than in the half of cases: decreased libido - at $46.2 \%$, hemorrhoids - at $42.9 \%$, body weight increase - at $40.0 \%$, pigment spots - at $25.0 \%$, cellulite - at $20.0 \%$.

Some distinctions of side effects in different groups of hormonal contraceptives were found. When using the medicines containing desogestrel, in $12.5 \%$ there were no side effects. In comparison with other hormonal contraceptives dizzinesses met $13.7 \% \operatorname{less}(\chi 2=6.28, \mathrm{p}<0.05)$. However all 4 cases of pigment spots were in this group of medicines $(7.1 \%)(\chi 2=8.08, \mathrm{p}<0.01)$.

In the group of contraceptivescontaining drospirenone there were no side effects in $7.4 \%$ of cases. Thus an abdominal pain, back pain, hypermenorrhea and dysmenorrhea, allergic rash didn't meet. $19.7 \%$ more women had increased appetite $(\chi 2=5.42, \mathrm{p}<0.05), 17.4 \%$ more - a breast pain $(\chi 2=6.69, \mathrm{p}<0.01), 15.2 \%$ more - a depression, low mood, fatigue $(\chi 2=4.49$, $p<0.05), 12.7 \%$ more - decreased libido $(\chi 2=5.12, p<0.05), 11.3 \%$ more - spotting in the second half of a cycle $(\chi 2=5.57, \mathrm{p}<0.05), 8.9 \%$ more - a leg pain $(\chi 2=5.22, p<0.05), 8.2 \%$ more - a skin itch $(\chi 2=3.81, p<0.05), 6.7 \%$ more -body weight decrease $(\chi 2=5.72, p<0.05)$.

When usingthe intrauterine system with levonorgestrel there were no side effects in $33.3 \%$ of cases. Dyspareuniawas $12.0 \%$ more often $(\chi 2=8.40, \mathrm{p}<0.01)$, and back pains $-10.7 \%$ more $(\chi 2=4.49$, $\mathrm{p}<0.05)$. Also there werea sleepiness, sleeplessness, dizziness, hemorrhoids, abdominal pain, blood pressure increase, hypermenorrhea and dysmenorrhea,spotting in the second half of a cycle, cellulite, leg pain, but not more than at other hormonal contraceptives $(\mathrm{p}<0.05)$. Other side effects weren't observed.

When comparing the medicines containing 20 and $30 \mathrm{mkg}$ of EE there were no distinctions in the general frequency of side effects. In the first group headaches were $21.3 \%$ less $(\chi 2=4.91, p<0.05)$. Butin the second group spotting in the second half of a cycle was observed $11.3 \%$ less $(\chi 2=3.95, p<0.05)$, and a low appetite didn't take place whereas in the first group its frequency was $10.8 \%(\chi 2=5.24, \mathrm{p}<0.05)$.

There were no significant distinctions in the frequency of side effects at the smoking women and nonsmoking, and also at taking and not taking alcohol $(\chi 2<3.8, \mathrm{p}>0.05)$.

At the questioned women with an excess body weight before using hormonal contraception the frequency of vaginal candidiasis was $16.9 \%$ more $(\chi 2=6.41, p<0.05)$. The respondents who had at the time of using an excess body weight in comparison with women with a normal weighthypermenorrhea and dysmenorrhea were $7 \%$ more $(\chi 2=4.22, \mathrm{p}<0.05)$.

There were no distinctions in the frequency of side effects at the respondents who had an irregular menstrual cycle or expressed premenstrual syndrome earlier $(\chi 2<3.8, p>0.05)$.

Some diseases that respondents had in the anamnesis increased the frequency of some side effects. At the women who had endometriosis frequency of spotting in the second half of a cycle was increased for $21.1 \%$ $(\chi 2=9.71, p<0.01)$.If they had ovary cysts in the anamnesis the breast increase met for $19.2 \%$ more often $(\chi 2=10.48, p<0.01)$. At the women who had inflammatory gynecologic diseases total number of side effects, on the contrary, was $12.1 \%$ less $(\chi 2=6.94, \mathrm{p}<0.05)$. Perhaps, it was caused by more careful choiceof a contraceptive and doctor's control.

Extragenital diseases also had impact on the frequency of side effects. Women who had a varix dilatation complained of nausea $36.2 \%$ more $(\chi 2=11.95, p<0.001)$, body weight increase $-23.8 \%$ more $(\chi 2=4.35, p<0.05)$, edemas and libido decrease-14.8\% more $(\chi 2=3.93, \mathrm{p}<0.05)$, hemorrhoids $-11.0 \%$ more $(\chi 2=3.85$, $\mathrm{p}<0.05)$. All women with kidneys and urinary system diseases had side effects. They noted a breast pain $18.7 \%$ more often $(\chi 2=4.44, \mathrm{p}<0.05)$, libido decrease $-14.8 \%$ more $(\chi 2=3.93, \mathrm{p}<0.05)$. At the respondents with diseases of a stomach, intestines, pancreas sleepinesswas $31.7 \%$ more often $(\chi 2=15.81, p<0.001)$, an increased appetite $-17.0 \%$ more $(\chi 2=4.23, \mathrm{p}<0.05)$, a low appetite $-10.9 \%$ more $(\chi 2=6.19, \mathrm{p}<0.05)$, libido decrease $-15.6 \%$ more $(\chi 2=8.08, \mathrm{p}<0.01)$. Mastopathy, arterial hypertension, anemia in the anamnesis had no significant impact $(\chi 2<3.8, p>0.05)$.

Some women reported that after using hormonal contraceptives new diseases were diagnosed for them. The most frequent was gastritis -almost every fifth woman admitted this (18.6\%). 8 of questioned women had an arterial hypertension, 6 - anemia, 5 -ovary cysts, 5 - eczema or dermatitis, 4 - diseases of urinary tract. Also there were cholelithiasis, migraine, cervical ectopia - everything for one case.

Hormonal contraception was effective at the most (97.2\%) of women - they didn't become pregnant when using this method. 4 women (2.8\%) became pregnant, but all that cases were caused by unregular tablets intake (figure 3). These data are comparable with that provided in literature. 


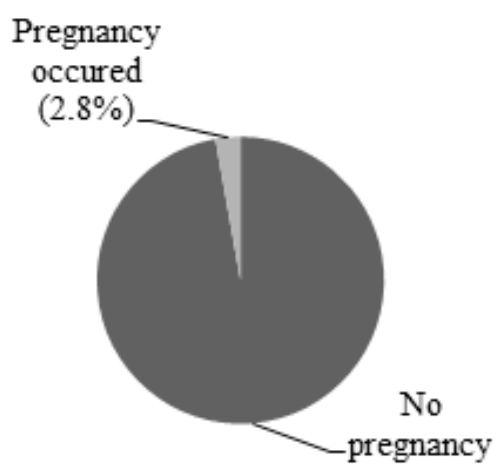

$(97.2 \%)$

Figure 3. Efficiency of hormonal contraceptives

When using hormonal contraception almost each woman noted any advantages. Three of five (60.0\%) respondents admitted the regularity of a cycle, the half of them - less painful periods $(51.0 \%)$ and no fear of undesirable pregnancy (48.3\%). Two of five respondents (40.7\%) noted less premenstrual syndrome manifestations, every third (33.8\%) - more active sexual life. Every fourth admitted a better quality of sexual life (26.2\%), better skin and hair condition, mood (24.8\%), and a breast engorgement decreased in everyfifth $(18.6 \%)$ woman. $5.5 \%$ of respondents answered that they became pregnant faster after the termination of using hormonal contraceptive, ovary cysts disappeared at $4.8 \%$,endometriosis symptoms decreased at $2.8 \%$.

The most of the questioned women (64.8\%) are satisfied that they used hormonal contraception, but almost every tenth (9.0\%) were not satisfied, and other $26.2 \%$ were at a loss with the answer (figure 4).

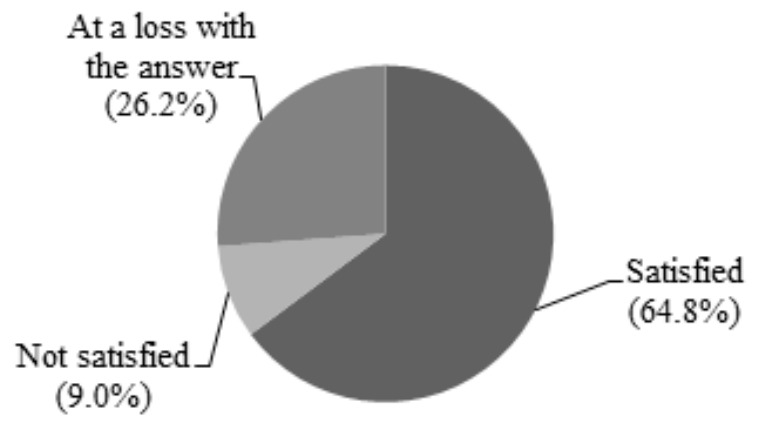

Figure 4. Satisfaction with method

The half (53.4\%) of respondents are ready to continue using this method, despite side effects, and every third $(29.0 \%)$ - if other hormonal contraceptive will be suitable and there will be no side effects. At the same time, every sixth (17.6\%) woman will refuse this method (figure 5).

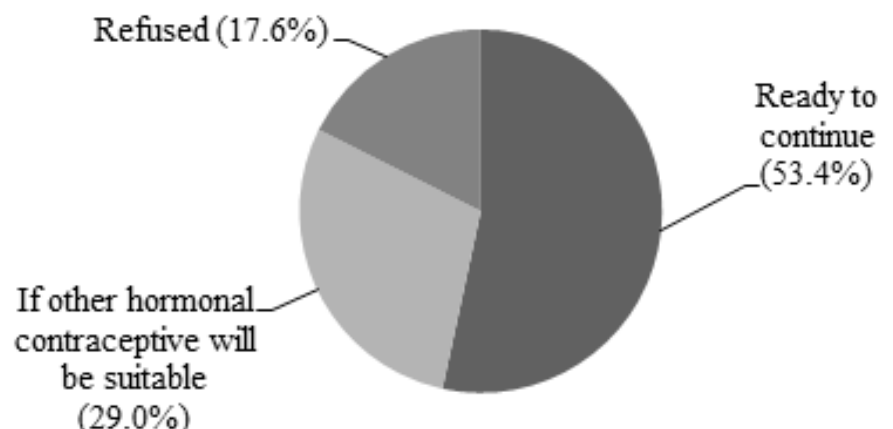

Figure 5. Readiness to continue using despite side effects

In the WHOQOL-BREF indicators on 4 spheres were valued: physical and psychological wellbeing, selfperception, microsocial support, social wellbeing. Besides, indicators of quality of life and a state of health were valued. All indicators were transferred to a scale from 1 to 100 . The average norm was 64 . 
Almost every tenth respondent (8.3\%) estimates the quality of life as very good, two of three (62.1\%) - as good, every fourth (25.5\%) - as neither bad nor good, and only a small share of women consider it is bad (3.4\%) or very bad (0.7\%) (figure 6). The average value was 68.4 \pm 1.4 .

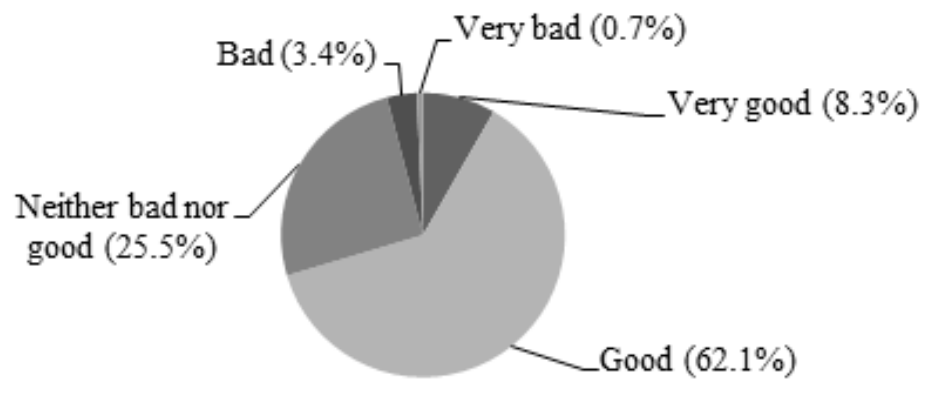

Figure 6. Quality of life

$2.8 \%$ were very satisfied of their condition of health, more than a half of respondents (56.6\%) were satisfied, the option "neither that nor another" was chosen by every fourth respondent (26.2\%), every eighth (12.4\%) wasn't satisfied, and $2.1 \%$ were very not satisfied (figure 7 ). The average value was $61.4 \pm 1.7$.

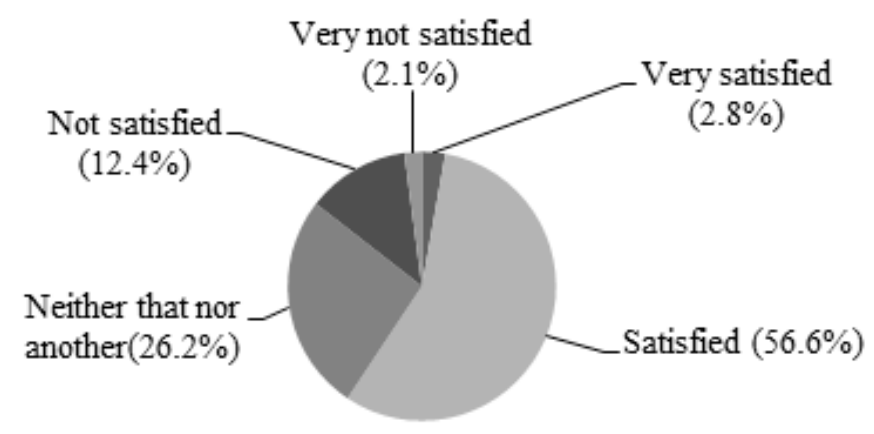

Figure 7. State of health

In the sphere of physical and psychological wellbeing the average value was $56.2 \pm 0.7$, self-perceptions $61.1 \pm 0.9$, microsocial support $-68.0 \pm 1.3$, social wellbeing $-61.5 \pm 1.0$. The average value on all spheres $-62.8 \pm 0.5$.

\section{Conclusions}

1. Hormonal contraceptives are highly effective at regular using.

2. Side effects are widespread and were found in 9 of 10 (90.4\%) women. However in $73.3 \%$ of cases they disappear during the first 3 months.

3. Some women admitted that new diseases were diagnosed for them in a usage time of hormonal contraception. Gastritis was almost at every fifth respondent (18.6\%), that requires attention.

4. The most of women are satisfied with hormonal contraception. Thehalf of respondents are ready to continue using despite side effects, and every third - if other hormonal contraceptive will be suitable and there will be no side effects.

5 . The quality of life of the women using hormonal contraceptives can be estimated as close to average norm.

6. The examination of women before using hormonal contraceptives and medical control allows to detail choosing of contraceptives, to estimate risk factors, to stop development of side effects in due time and to reduce refusals of hormonal contraception.

\section{References:}

1. Шмелева ЕВ, Зиганшина ЛЕ, Салихов ИГ. Побочные эффекты гормональных контрацептивов. Казанский медицинский журнал. 2006; 87(5): 366-9 (in Russian).

2. Пересада ОА. Эстроген-гестагенные препараты: альтернатива профилактики и лечения гинекологических заболеваний. Медицина. 2003; 43(4): 53-7 (in Russian). 
3. Brynhildsen J. Combined Hormonal Contraceptives: Prescribing Patterns, Compliance, and Benefits versus Risks. Therapeutic Advances inDrug Safety. 2014; 5: 201-13.

4. World Health Organization. Selected practice recommendations for contraceptive use. Geneva 2004.

5. Beckmann C, Ling F, Barzansky B, Bates W, Herbert W, Laube D et al. Obstetrics and gynecology. Kansas City: Williams \& Wilkins; 1998.

6. Collaborative Group on Epidemiological Studies of Ovarian Cancer, Beral V, Doll R, Hermon C, Peto R, Reeves G. Ovarian cancer and oral contraceptives: collaborative reanalysis of data from 45 epidemiological studies including 23257 women with ovarian cancer and 87303 controls. Lancet. 2008; Jan 26;371(9609): 303-14.

7. Cleland J, Conde-Agudelo A, Peterson H, Ross J, Tsui A. Contraception and health. Lancet. 2012; Jul 14;380(9837): 149-56.

8. Khalili H, Higuchi LM, Ananthakrishnan AN, Richter JM, Feskanich D, Fuchs CC et al. Oral Contraceptives, Reproductive Factors and Risk of Inflammatory Bowel Disease. Gut. 2013 Aug; 62(8): 1153-9.

9. Алесина ИЛ. Консультирование женщин как важный инструмент при индивидуальном подборе метода контрацепции. Акушерство и гинекология. 2011; 6: 120-4 (in Russian).

10. Бостанджян ЛЛ., Прилепская В.Н. Комбинированная гормональная контрацепция в вопросах и ответах. Акушерство и гинекология. 2011; 5: 129-33 (in Russian).

11. Пересада ОА. Приемлемость использования гормональных контрацептивов у женщин с особенностями соматического состояния.Медицина. 2003; 43(4): 49-52 (in Russian).

12. ШатуноваЕП,Степанова Ю.В.Применениегормональныхконтрацептивов впрограммереабилитации после перенесенного обострения хронического сальпингоофорита. Акушерство и гинекология. 2011; 2: 106-10 (in Russian).

13. Сметник ВП, Тумилович Лг. Неоперативная гинекология: Руководство для врачей. Медицинское информационное агентство, Москва 2006 (in Russian).

14. Кулаков ВИ, Савельева ГМ, Манухин ИБ. Гинекология. Национальное руководство. Москва: ГЭОТАРМедиа; 2009 (in Russian).

15. Национальный статистический комитет Республики Беларусь, Детский фонд ООН (ЮНИСЕФ). Многоиндикаторное кластерное обследование по оценке положения детей и женщин в Республике Беларусь. 2012 год. Итоговый отчет. Минск 2013 (in Russian).

16. Министерство здравоохранения Республики Беларусь, РНПЦ медицинских технологий, информатизации, управления и экономики здравоохранения. Здравоохранение в Республике Беларусь: официальный статистический сборник за 2013 г. ГУ РНМБ, Минск 2014 (in Russian).

17. Тихомиров АЛ. Необходимость и обоснованность современной гормональной контрацепции. ОРЖИН. 2008; 5 (спецвыпуск): 2-5 (in Russian). 